Snežana Knežević ${ }^{1}$, Ksenija Mandić ${ }^{, A l e k s a n d r a ~ M i t r o v i c ́ ², ~ V e l j k o ~ D m i t r o v i c ́ 1 ~}{ }^{\text {, Boris Delibašić }}{ }^{1}$

1 University of Belgrade, Faculty of Organizational Sciences, Serbia

2University of Kragujevac, Faculty of Hotel Management and Tourism, Serbia

\title{
An FAHP-TOPSIS Framework for Analysis of the Employee Productivity in the Serbian Electrical Power Companies
}

DOI: 10.7595/management.fon.2017.0011

\begin{abstract}
The aim of this paper is to apply an integrated model, which combines methods of classical and fuzzy Multi-criteria decision making (MCDM) in selected six large equity companies from the Serbian energy sector. The data considered are retrieved from the official financial statements. Four main criteria were analyzed, identified by the previous researchers and pointing to the employees' productivity: Operating income/Number of employees, Equity/Number of employees, Net income/Number of employees and Total assets/Number of employees. The contribution of this paper lies in the application of a hybrid model that integrates two MCDM methods: Fuzzy Analytic Hierarchy Process (FAHP) and Technique for Order Performance by Similarity to Ideal Solution (TOPSIS) to analyse the employee productivity in selected D-Electrical power supply companies operating in Serbia. The FAHP is an effective method for mathematical representation of uncertain and imprecise evaluations made by humans, while the TOPSIS method is an efficient way to rank the alternatives. Results show that operating income is of highest importance for estimating employee productivity and decision making, while equity is of the weakest. Furthermore, the most productive operations in large enterprises from selected companies of the sector D-Electrical power supply are found in the company PC EPS Beograd, and the lowest are in the ED Center Ilc Kragujevac.
\end{abstract}

Keywords: employee productivity, Serbian companies, electricity sector, fuzzy logic, MCDM methods, FAHP, TOPSIS.

JEL classification: C20, C60, P28, Q40, J24

\section{Introduction}

Continuous technological progress puts more complex demands before company employees. In this context, the management of the company is expected to activate all relevant components through appropriate organisational structures to increase the productivity of employees.

Employees can create added value, and this stems from a combination of factors of the situation and characteristics of workers, primarily of a manager, who represents the driving force of the company. Stewart (1991) defined intellectual capital (IC) as "knowledge, information, intellectual property, experience - that can be put to use to create wealth". Roos et al. (2005) classify intellectual capital into human capital, organisational capital, and relational capital. According to Peng et al. (2007), "intellectual capital is the set of critical resources used by firms to facilitate productive activities and generate economic rents". Employees represent the intellectual equity of the company if they have a sufficient amount of formal education, experience and ability, learned reflex or even talent to react in a crisis and expected situations in order to make more 
accurate business decisions (Lentjusenkova \& Lapina 2016). This equity merges into the enterprise and creates value thereof. The efficiency of the company is an expression of performance adjustment to market environment and internal operating conditions, which is necessary for the survival, growth and development. The efficiency of enterprises is a synthetic indicator of the output to input relation, i.e., it demonstrates the successfulness of a company in the use of resources at its disposal - material and human resources. In this context, it is especially important nowadays that companies develop a mechanism for proper management of the employee productivity. Also necessary for this is an appropriate reporting system, both at the enterprise level and at the narrower organisational department one, as well as a strong support of information technology.

According to classical economic theory, efficiency is measured as the ratio between one output and one input. However, in practice, this is much more complex as the entities have many different inputs and outputs. The problem arises if you cannot find a common term for them. Generally speaking, the principle of efficiency is achieved if there are the highest possible economic effects of output values (output) with minimum economic investment (input). It should especially be borne in mind that in times of economic crises, each company must perceive competitors in order to improve the efficiency of operations.

Efficiency is measured as the ratio between one output and one input and companies have many diverse inputs and outputs (Markovic et al., 2015). Productivity is an important instrument for increasing the overall efficiency of banks (Andries, 2011) and insurance companies. To manage the productivity of employees in enterprises, it is possible to use different ratios, as follows (Knezevic, 2006):

- Operating income/Total number of employees in the company;

- Operating income/Number of full time employees in the company;

- Operating income/Total number of effective work hours;

- Net income/Total number of employees in the company;

- Net income/Number of full time employees in the company;

- Equity/Total number of employees in the company;

- Equity/Total number of full time employees in the company;

- Net profit/Number of organisational units of the company;

- Net income/Total number of effective working hours;

- Profit centre income/Total number of employees in the profit center;

- Profit centre income/Total number of full time employees in the profit center;

- Profit centre income/Total number of effective working hours, as well as many other indicators.

"Efficiency shows the degree of effectiveness of the companies that have specific inputs (equity and reserves, deposits, borrowings, engaged funds, property) for the production or services to obtain the output values, e.g., revenues and profit" (Knezevic et al., 2015). Equity and Total assets are the key inputs presented in the balance sheet. Operating income and Net income are the key financial outputs presented in the income statement. Inputs and outputs are correlated. As a base for research in this paper four coefficients were used to test the productivity of employees, as follows: 1) Operating income/Number of employees, 2) Equity/Number of employees, 3) Net income/Number of employees and 4) Total assets/Number of employees. The number of workers can be expressed in two ways, that is, as the strength of the workers who are on the job and as the average number of employees based on working hours.

The study includes the sample of six companies among the largest first-ranked by the equity in Serbia. The criteria for selection was the high degree of concentration of financial power for companies operating in the same sector (electricity power supply, six top-ranked) and which are classified as large companies. For the selected companies, public accessible, relevant financial information and data were taken from the Agency for Business Registers. There are financial reports of companies published, as well as statistics on the number of employees from the same source (http://www.apr.gov.rs/, 2017).

The starting hypothesis of the research is: The use of linguistic variables, which are expressed by triangular fuzzy numbers, allows decision-makers to calculate more realistic weights of criteria and thus enable more effective ranking of alternatives. The aim of this research is to analyse the employee productivity in se- 
lected Serbian electrical power companies by using FAHP-TOPSIS model. Within the paper, an integrated model for ranking the companies from the sector of the D-electrical power supply is proposed by four coefficients of employee productivity. This model combines the method of fuzzy MCDM such as FAHP and the method of classical MCDM such as TOPSIS. The objective of this paper is to determine the priority weights for four primary coefficients of employee productivity using FAHP method; while using the TOPSIS method ranking of the companies from the sector of the D-electrical power supply is performed on the basis of the mentioned coefficients. It is of practical interest to explore how classical and fuzzy MCDM methods can be combined and the manner in which they contribute to the process of ranking. The priority vectors for the selected criteria are set by including the fuzzy MCDM (FAHP) method in the research. This method involves the use of fuzzy numbers and thus does not require precise (numerically determined) information. By using this method, it is possible to work with uncertain and imprecise data. On the other hand, using the classical MCDM method, TOPSIS enabled the ranking of companies and in this way it is possible to determine which company is closer to the Positive Ideal Solution or farther to the Negative Ideal Solution.

The paper is structured as follows. Section 2 presents a brief literature overview about productivity and application of the different models. Section 3 points to the used sample and methodology. However, the appendix covers a brief outline of the used FAHP and TOPSIS methods. Besides, a used model constructed by integrating the presented MCDM methods is also presented. The proposed model allows the ranking of large companies from the sector of D-electrical power supply concerning the productivity of employees. Section 4 presents findings, results and discussion. The paper ends with concluding remarks in Section 5 .

\section{Literature overview}

Economic engagement of the factors of production in the field of production of goods and generating services where sales price exceeds the costs is more and more in the focus of new entrepreneurship due to increasingly complex operating conditions and tough competition in the market. In this framework, there is a close connection between economics and management in the company and the way their relationship determines their effectiveness and efficiency at the company level. Indicators focused on the relationship between a company's input and output elements are productivity, efficiency and profitability. In the economic theory discussed and in the economic practices implemented there are various quantitative (and qualitative) sets of indicators.

Productivity should be monitored in relation to the planned size or realisation of similar size (comparable) companies, but the comparison with the leader in the relevant branch should also be monitored. According to Knezevic et al. (2012), productivity can be measured as a quotient of one output and one input; then the obtained indices are divided from one period to another. One of the plans of strategic importance for the company is the plan of measures to increase the company's productivity.

According to Knezevic (2006), factors of labour productivity in enterprises can in principle be systematised in two parts, objective factors and subjective factors) or in three parts:

(1) absolutely objective factors - general economic conditions (the pace of development of science and technology, market development);

(2) relatively objective factors - specific economic conditions in the market (location and capacity of the company, financial strength and business orientation, technology, organisation) and

(3) subjective factors of company - specific activities - managing company, motivating employees, staff attitudes, working conditions and employees' living conditions).

Economic efficiency and an increase of labour productivity are of particular interest due to their importance for progress in any field and level. Based on particular research interests issue of productivity can be analysed. There are productivity differences due to many factors (Syverson, 2011). In recent years, innovation and new technologies are seen as factors that have a significant influence on productivity and organisational performances (Skare and Tomic, 2016). There are several methods and models which are used for measuring productivity and efficiency of decision-making units. The most popular methods of evaluation and benchmarking for performances of decision-making units are Data Envelopment Analysis (DEA), Stochastic Frontier Analysis and Distance Based Analysis (DBA) (Çelen, 2013; Jayaraman et al., 
2013). Many factors can have an impact on the efficiency and productivity but also can be mutually conflicted. Due to this fact, multiple-criteria decision-making (MCDM) is necessary to be implemented. In the literature a multitude of papers can be found that have developed models based on the MCDM methods. In most of the papers, in addition to the classic MCMD method, also used is the theory of fuzzy sets, as an effective way to mathematically represent vague and imprecise human preferences. In recent years, numerous authors applied classical MCDM method in combination with fuzzy methods for choosing the optimal solution: Patil \& Kant (2014) created a fuzzy AHP-TOPSIS framework for ranking the solutions of knowledge management adoption in the supply chain to overcome its barriers. On the other hand, Prakash \& Barua (2015) integrated AHP-TOPSIS method for prioritising the solutions of reverse logistics adoption to overcome its barriers under fuzzy environment. Also, Zyoud et al. (2016) proposed the integrated FAHPFTOPSIS model for dealing with complicated issues in the context of water loss management. Hosseini \& Keshavarz (2017) used FAHP and FTOPSIS for strategic analysis measurement of service quality in the banking industry. To analyse the e-service quality of banking internet Özdaðoðlu (2016) combined FAHP and FTOPSIS, while Keshavarz et al. (2014) use the same combination of methods for prioritisation of technological competencies to maximise the financial and non-financial performance. Mandic et al. (2014) analysed financial parameters of Serbian banks through the application of the fuzzy AHP and TOPSIS methods. Pramanik et al. (2017) dealt with resilient supplier selection using AHP-TOPSIS-QFD under a fuzzy environment. Tadic et al. (2014) evaluated and ranked the organisational resilience factor by using FAHP and FTOPSIS. Also, Tadic et al. (2013) used the same methods to evaluate quality goals. Kannan et al. (2014) used FTOPSIS for selecting a green supplier. Vinodh et al. (2014) integrated FAHP-TOPSIS for selecting the best plastic recycling method. Lima Junior et al. (2014) compared FAHP and FTOPSIS methods to supplier selection. Samvredi et al. (2013) integrated FAHP-FTOPSIS to quantify risks in a supply chain. Onar et al. (2014) used hesitant FTOPSIS and Interval type-2 FAHP for strategic decision selection.

Therefore, in this paper an integrated model that combines the fuzzy AHP method and classical MCDM method for ranking TOPSIS is applied. The FAHP method is used to determine the priority weights of employee productivity criteria being analysed, whereas the TOPSIS method is used to rank the electrical companies in Serbia.

The application of the classical MCDM method and fuzzy methods for analysing the electrical power supply and distribution sector can be found in the following studies. Bas (2013) has proposed the SWOT-fuzzy TOPSIS methodology combined with AHP for analysis of electricity supply chain in Turkey. Kabir \& Sumi (2014) have integrated FAHP and PROMETHEE methods to select power substation location (case study from Bangladesh). On the other hand, et al. (2015) used FTOPSIS for ranking renewable energy supply systems in Turkey. Also, Zare et al. (2015) analysed the electricity supply chain using AHP and FTOPSIS. Choudhary \& Shankar (2012) have introduced fuzzy AHP-TOPSIS framework for evaluation and selection of thermal power plant location in India.

\section{Sample and Methods}

In this section, the integrated multi-criteria model for the analysis of employee productivity in the companies of the sector D-Electrical power supply operating on the territory of Serbia will be presented. The data considered are retrieved from the official financial statements displayed on the website of the Agency for Business Registers. The study includes the sample of six large companies from the sector D-Electrical power supply. Four basic criteria were analysed identified by the financial experts pointing to the employee productivity: Operating income/Number of employees, Equity/Number of employees, Net income/Number of employees and Total assets/Number of employees. The model is created integrating two methods of fuzzy and multi-criteria decision-making such as: Fuzzy Analytic Hierarchy Process - FAHP and Technique for Order Performance by Similarity to Ideal Solution - TOPSIS. The FAHP method uses the priority vectors for decision-making criteria. This method uses linguistic variables and thus enables decision makers to represent the vague statements in a much simpler manner. On the other hand, the TOPSIS method is used for effectively ranking the alternatives based on the distance from the Positive Ideal Solution (PIS) and Negative Ideal Solution (NIS). A detailed overview of the employed framework is presented in Appendix and papers Mandic et al. (2017), Mandic et al. (2014). 


\section{Findings and Results}

The first step within the FAHP method defines the research goal, in our case, „The analysis of employee productivity in the companies from the sector D-Electrical power supply operating in the territory of Serbia". For this purpose, four basic criteria of employee productivity were considered: Operating income/Number of employees, Equity/Number of employees, Net income/Number of employees and Total assets/Number of employees. Further, in the second step the priority weights were calculated for each of the criteria individually using the Logistical scale of importance (Table 1). The linguistic scale of importance (Kilincci \& Onal, 2011) shows the manner in which the linguistic variables convert into triangular fuzzy numbers.

Table 1: Linguistic scale of importance

\begin{tabular}{lll}
\hline Linguistic scale of importance & Triangular fuzzy numbers & $\begin{array}{l}\text { Reciprocal value of } \\
\text { triangular fuzzy numbers }\end{array}$ \\
\hline Equal & $(1,1,1)$ & $(1,1,1)$ \\
Weak & $(1 / 2,1,3 / 2)$ & $(2 / 3,1,2)$ \\
Fairly Strong & $(3 / 2,2,5 / 2)$ & $(2 / 5,1 / 2,2 / 3)$ \\
Very strong & $(5 / 2,3,7 / 2)$ & $(2 / 7,1 / 3,2 / 5)$ \\
Absolute & $(7 / 2,4,9 / 2)$ & $(2 / 9,1 / 4,2 / 7)$ \\
\hline
\end{tabular}

Source: Author's Analysis

Within Table 2 a comparison is given of four basic criteria of employee productivity using the triangular fuzzy numbers and their reciprocal values, based on which priority weights were calculated (Wc) for each criterium individually.

Table 2: Fuzzy comparison matrix for four attributes with respect to the objective and its priority vectors

\begin{tabular}{|c|c|c|c|c|c|}
\hline Criteria & $\begin{array}{c}\text { Operating } \\
\text { income/Number } \\
\text { of employees }\end{array}$ & $\begin{array}{l}\text { Equity/Number } \\
\text { of employees }\end{array}$ & $\begin{array}{c}\text { Net } \\
\text { income/Number } \\
\text { of employees }\end{array}$ & $\begin{array}{c}\text { Total } \\
\text { assets/Number } \\
\text { of employees }\end{array}$ & $\begin{array}{l}\text { Priority } \\
\text { vector } \\
(\mathrm{Wc})\end{array}$ \\
\hline \multicolumn{6}{|l|}{ Operating } \\
\hline $\begin{array}{l}\text { income/Number } \\
\text { of employees }\end{array}$ & $(1,1,1)$ & $(3 / 2,2,5 / 2)$ & $(1 / 2,1,3 / 2)$ & $(3 / 2,2,5 / 2)$ & 0.349548 \\
\hline $\begin{array}{l}\text { Equity/Number } \\
\text { of employees }\end{array}$ & $(2 / 5,1 / 2,2 / 3)$ & $(1,1,1)$ & $(2 / 5,1 / 2,2 / 3)$ & $(1 / 2,1,3 / 2)$ & 0.131118 \\
\hline Net & & & & & \\
\hline $\begin{array}{l}\text { income/Number } \\
\text { of employees } \\
\text { Total }\end{array}$ & $(2 / 3,1,2)$ & $(3 / 2,2,5 / 2)$ & $(1,1,1)$ & $(1 / 2,1,3 / 2)$ & 0.299606 \\
\hline $\begin{array}{l}\text { assets/Number } \\
\text { of employees }\end{array}$ & $(2 / 5,1 / 2,2 / 3)$ & $(2 / 3,1,2)$ & $(2 / 3,1,2)$ & $(1,1,1)$ & 0.219728 \\
\hline
\end{tabular}

Source: Author's Analysis

Table 2 shows that in the process of estimating the employee productivity, the criteria Operating income/Number of employees has the highest importance with the weight vector of 0.349; the second is Net income/Number of employees with 0.300 , the third is Total assets/Number of employees with 0.220 , whereas the fourth place belongs to Equity/ Number of employees with 0.131 .

Table 3 shows relevant data for the companies in sector D-Electrical power supply retrieved from the financial statements of the Agency of Business registers. As shown in Table 3, six large companies from sector D-Electrical power supply were chosen, operating in the territory of Serbia. 
Table 3: Values of the companies productivity

\begin{tabular}{|c|c|c|c|c|}
\hline Large companies & $\begin{array}{c}\text { Operating } \\
\text { income/Number } \\
\text { of employees } \\
(0.349)\end{array}$ & $\begin{array}{c}\text { Equity/Number } \\
\text { of employees } \\
\text { (0.131) }\end{array}$ & $\begin{array}{c}\text { Net } \\
\text { income/Number } \\
\text { of employees } \\
(0.300)\end{array}$ & $\begin{array}{c}\text { Total assets } \\
\text { /Number of } \\
\text { employees } \\
(0.220)\end{array}$ \\
\hline PC EPS BEOGRAD & 298205,9589 & 534681,3112 & 3680,596869 & 846483,1331 \\
\hline $\begin{array}{l}\text { ELEKTROSRBIJA DOO } \\
\text { KRALJEVO }\end{array}$ & 9200,686064 & 25943,39033 & 1186,394808 & 35066,60161 \\
\hline $\begin{array}{l}\text { ELEKTROVOJVODINA DOO } \\
\text { NOVI SAD }\end{array}$ & 13714,58856 & 25481,0288 & 813,6927022 & 33705,09744 \\
\hline PC EMS BEOGRAD & 14070,63279 & 42962,28116 & 1206,316766 & 63889,12908 \\
\hline EDB DOO BEOGRAD & 17824,99126 & 25514,98486 & 1356,179965 & 34534,62493 \\
\hline $\begin{array}{l}\text { ED CENTAR DOO } \\
\text { KRAGUJEVAC }\end{array}$ & 8985,598258 & 21265,27396 & 672,5459826 & 32564,97483 \\
\hline
\end{tabular}

Source: Author's Analysis

After determining weight vectors for the criteria of productivity of employees using FAHP methodology, the next step suggested within this paper is using the TOPSIS method for ranking the companies. Within the TOPSIS method, the first phase is normalisation of decision-making matrix, followed by the calculation of the weighted normalised matrix so that the normalised matrix is multiplied by FAHP weight vectors for the productivity criteria. Then the shortest distance from the PIS and the farthest distance from the NIS are determined. After calculating PIS and NIS, it is possible to obtain the similarity coefficients $\left(C C_{j}\right)$ for each alternative. Table 4 presents the display parameters PIS, NIS, $C_{i}$ and Rank for large enterprises. Table 4 shows the parameters PIS, NIS and $\mathrm{CC}_{i}$ and Ranking for large companies. The primary goal of the TOPSIS method is to consider simultaneously both PIS and NIS distances so that at the end the ideal solution is calculated closest to PIS and farthest from NIS.

Table 4: PIS, NIS, CCi and the Ranking of enterprises Source: Author's Analysis

\begin{tabular}{lcccc}
\hline Large companies & $\mathrm{d}+$ & $\mathrm{d}-$ & $\mathrm{Cci}$ & Rank \\
\hline PC EPS BEOGRAD & 0 & 0.464026 & 1 & 1 \\
ELEKTROSRBIJA LLC KRALJEVO & 0.44883833 & 0.035058 & 0.07244865 & 4 \\
ELEKTROVOJVODINA LLC NOVI SAD & 0.45541963 & 0.011139 & 0.02387425 & 5 \\
PC EMS BEOGRAD & 0.43947313 & 0.038114 & 0.07980507 & 3 \\
EBD LLC BEOGRAD & 0.43712221 & 0.047745 & 0.09847014 & 2 \\
ED CENTER LLC KRAGUJEVAC & 0.46402599 & 0 & 0 & 6 \\
\hline
\end{tabular}

Table 4 shows that the most productive operations in large enterprises from sector D-Electrical power supply were performed by the company PC EPS Beograd, followed by EBD Ilc Beograd, PC EMS Beograd, Elektrosrbija Ilc Kraljevo, Elektrovojvodina Ilc Novi Sad and finally ED Center Ilc Kragujevac.

Operating incomes are a key factor in operating profit, and it is of particular importance to financial performance metrics. For measuring the productivity of employees concerning the actual financial performance on an annual basis in the company, operating incomes are an especially important factor for assessing the real efficiency of the companies. The structure of total incomes regarding the allocation, and thus the operating income as its integral part, is made of the expenditures of the production elements (cost of items of work, means of work and labour), as well as gains. The greatest opportunities for increasing labour productivity are precisely in an adequate drive of the human factor. In this sense, gaining even greater importance in the productivity metrics is the operating income criterion. Staff motivation is conditioned by the manner of rewarding and incentives implemented by the company management. 


\begin{abstract}
It is also necessary to emphasize that excessive workloads placed before the employees can negatively affect the results of the productivity metrics, thus, in addition to monitoring the productivity in the company, the fluctuation of employees should also be analyzed (number of newly admitted workers in relation to the total number of employees, the number of employees who left the company in relation to the total number of employees and the number of replacement workers in relation to the total number of employees). Frequent employee fluctuation regarding leaving the workplace may indicate that the employees of a particular company cannot keep the required operating pace as it is defined following the actual standards, in the long run.
\end{abstract}

\title{
Conclusion
}

The primary purpose of this research is to apply a hybrid model which is based on a combination of classical and fuzzy MCDM methods to analyse the problem of employee productivity in electrical power supply companies of Serbia. The used model allows for the priority vectors for the selected criteria of productivity of employees to be determined. Besides, the model also allows ranking of the selected companies. The results of this paper demonstrate the capability and effectiveness of the proposed model in choosing the most appropriate electrical company in accordance with the analysis the employee productivity problem.

In the paper, the integrated model combining the two methods of multi-criteria decision analysis was developed: Fuzzy AHP and TOPSIS. As it can be seen from the study, in the first step we determined the priority weights for the four basic criteria of productivity using the FAHP: Operating income/Number of employees, Equity/Number of employees, Net income/Number of employees and Total assets /Number of employees. We have concluded that the most important criterion is Operating income/Number of employees with a weight vector of 0.349 , the second is Net income/Number of employees with 0.300 , the third is Total assets/Number of employees with 0.220 , while the forth place is occupied by Equity/Number of employees with 0.131 . The next step taken in this study is the ranking of large enterprises from sector D-electrical power supply by using the TOPSIS method. This method enabled the determination of the distances of each alternative from PIS and NIS, and thus an ideal solution was obtained which was nearest to PIS and farthest from the NIS. Among large companies, PC EPS Beograd was ranked as a company that achieved the best results according to the selected criteria of productivity, followed by EBD Ilc Beograd, PC EMS Beograd, Elektrosrbija Ilc Kraljevo, Elektrovojvodina Ilc Novi Sad and, finally, ED Center Ilc Kragujevac.

The electricity market of the Republic of Serbia remains dominant, depending on the actual trends in the segment of operating incomes, so that in making decisions particular attention should be paid to it, bearing in mind the exposure of the companies to competition risk. Having also in mind that the market of the Republic of Serbia remains distinctive in that it is characterized by the pressure of disloyal competition, which in terms of a small number of market participants and the existence of market concentrations allows a misuse of a dominant position by several largest producers (especially in the case of restrictions on the transmission network), gives the efficiency increase even greater significance.

The main limitation of this research, is indicated to be the possibility of obtaining better results by combining two fuzzy methods, or by a combination of three or more MCDM methods. Therefore, future research will be dedicated to combining more classical and fuzzy MCDM methods to determine whether the development of such models can provide better and more relevant results in the ranking procedure.

\section{REFERENCES}

[1] Abo-Sinna, M. A., \& Amer, A. H. (2005). Extensions of TOPSIS for multi-objective large-scale nonlinear programming problems. Applied Mathematics and Computation, 16, 243-256. DOI: 10.1016/j.amc.2003.12.087

[2] Agency for Business Registers, Retrieved from http://www.apr.gov.rs/

[3] Andries A. M. (2011). The Determinants of Bank Efficiency and Productivity Growth in the Central and Eastern European Banking Systems. Eastern European Economics, 49(6), 38-59, DOI: 10.2753/EEE0012-8775490603

[4] Bas, E. (2013). The integrated framework for analysis of electricity supply chain using an integrated SWOT-fuzzy TOPSIS methodology combined with AHP: The case of Turkey. International Journal of Electrical Power \& Energy Systems, 44(1), 897-907. DOI: 10.1016/j.ijepes.2012.08.045

[5] Benitez, J. M., Martin, J. C. \& Roman, C. (2007). Using fuzzy number for measuring quality of service in the hotel industry. Tourism Management, 28(2), 544-555. DOI: 10.1016/j.tourman.2006.04.018 
[6] Buckley, J. J. (1985). Fuzzy hierarchical analysis. Fuzzy Sets and Systems, 17(3), 233-247. DOI: 10.1016/0165-0114(85)90090-9

[7] Büyüközkan, G., Feyzioglu, O. \& Nebol, E. (2008). Selection of the strategic alliance partner in logistics value chain. International Journal of Production Economics, 113(1), 148-158. DOI: $10.1016 / j . i j p e .2007 .01 .016$

[8] Çelen, A. (2013). Efficiency and productivity (TFP) of the Turkish electricity distribution companies: An application of two-stage (DEA\&Tobit) analysis. Energy Policy, 63, 300-310.

[9] Chang, D.Y. (1996). Applications of the Extent Analysis Method on Fuzzy AHP. European Journal of Operational Research, 95(3), 649-655. DOI: 10.1016/0377-2217(95)00300-2

[10] Choundhary, D. \& Shankar, R. (2012). A STEEP-fuzzy AHP_TOPSIS framework for evaluation and selection of thermal power plant location: A case study from India. Energy, 42(1), 510-521. DOI: 10.1016/j.energy.2012.03.010

[11] Dubois, D. \& Prade, H. (1978). Operations on Fuzzy Numbers. International Journal of system science, 9(3), 613-626. DOI: 10.1080/00207727808941724

[12] Gumus, A.T. (2009). Evaluation of hazardous waste transportation firms by using a two-step fuzzy-AHP and TOPSIS methodology. Expert Systems with Applications, 36, 4067-4074. DOI: 10.1016/j.eswa.2008.03.013

[13] Hosseini, M.H. \& Keshavarz, E. (2017). Using fuzzy AHP and fuzzy TOPSIS for strategic analysis measurement of service quality in banking industry. International Journal of Applied Management Science, 9(1). DOI: 10.1504/IJAMS.2017.082414

[14] Hwang, C. L. \& Yoon, K. (1981). Multiple attributes decision making methods and applications. Berlin: Springer.

[15] Jahanshahloo, G. R., HosseinzadehLotfi, F. \& Izadikhah, M. (2006). An algorithmic method to extend TOPSIS for decision-making problems with interval data. Applied Mathematics and Computation, 175(2), 1375-1384. DOI: 10.1016/j.amc.2005.08.048

[16] Jayaraman, A. R., Srinivasan, M. R., \& Jeremic, V. (2013). Empirical Analysis of Banks in India using DBA and DEA. Management- Journal for Theory and Practice Management, (1820-0222), 69. DOI: 10.7595/management.fon.2013.0029

[17] Kabir, G. \& Sumi, R.S. (2014). Power substation location selection using fuzzy analytic hierarchy process and PROMETHEE: A case study from Bangladesh. Energy, 72(1), 717-730. DOI: 10.1016/j.energy.2014.05.098

[18] Kahraman, C., Gulbay, M. \& Kabak, O. (2006). Applications of Fuzzy Sets in Industrial Engineering: A Topical Classification in: Fuzzy Application in Industrial Engineering, Springer, New York, 1-55. DOI: 10.1007/3-540-33517-X 1

[19] Kannan, D., Jabbour, A.B.L.S. \& Jabbour, C.J.C. (2014). Selecting green suppliers based on GSCM practices: Using fuzzy TOPSIS applied to a Brazilian electronics company. European Journal of Operational Research, 233(2), 432-447. DOI: 10.1016/j.ejor.2013.07.023

[20] Keshavarz, E., Heydari, T., Rohani, A. \& Bagheri, S. A. (2014). Using fuzzy AHP and fuzzy TOPSIS methods for prioritisation of technological competencies to maximise the financial and non-financial performance. International Journal of Business Information Systems, 16(3). DOI: 10.1504/IJBIS.2014.063769

[21] Kilincci, O. \& Onal, S.A. (2011). Fuzzy AHP Approach for Supplier Selection in a Washing Machine Company. Expert systems with applications, 38(8), 9656-9664. DOI: 10.1016/j.eswa.2011.01.159

[22] Knezevic, S. (2006). Strategic decision making in banks based on the management accounting information. Belgrade: Belgrade Business School.

[23] Knezevic, S., Markovic, M. \& Barjaktarovic Rakocevic, S. (2012). Assessing Efficiency in Banking, Industry, 40(3), 71-92.

[24] Knezevic, S., Markovic, M. \& Brown, A. (2015). Measuring the efficiency of Serbian insurance companies. Acta Oeconomica, 65(1), 91-106. DOI: 10.1556/AOecon.65.2015.1.5

[25] Lentjusenkova, O. \& Lapina I. (2016). The transformation of the organization's intellectual capital: from resource to capital. Journal of Intellectual Capital, 17(4), 610-631, DOI: 10.1108/JIC-03-2016-0031

[26] Lima Junior, F.R., Osiro, L. \& Carpinetti, L.C.R. (2014). A comparison between Fuzzy AHP and Fuzzy TOPSIS methods to supplier selection. Applied Soft Computing, 21 (2014), 194-209. DOI: 10.1016/j.asoc.2014.03.014

[27] Mandic, K., Delibasic, B., Knezevic, S. \& Benkovic, S. (2014). Analysis of the financial parameters of Serbian banks through the application of the fuzzy AHP and TOPSIS methods. Economic Modelling, 43(2014), 30-37. DOI: 10.1016/j.econmod.2014.07.036 
[28] Mandic, K., Delibasic, B., Knezevic, S. \& Benkovic, S. (2017). Analysis of the efficiency of insurance companies in Serbia using the fuzzy AHP and TOPSIS methods. Economic research-Ekonomska istraživanja, 30(1), 550-565. DOI: 10.1080/1331677X.2017.1305786

[29] Markovic, M., Knezevic, S., Brown A. \& Dmitrovic, V. (2015), Measuring the Productivity of Serbian Banks using Malmquist Index. Management - Journal for Theory and Practice Management, 76, 1-76 DOI: 10.7595/management.fon.2015.0022

[30] Onar, S.C., Oztaysi, B. \& Kahraman, C. (2014). Strategic Decision Selection Using Hesitant fuzzy TOPSIS and Interval Type-2 Fuzzy AHP: A case study. International Journal of Computational Intelligence Systems, 7(5), 1002-1021. DOI: 10.1080/00207543.2012.741330

[31] Özdağoğlu, A. (2016). E-service quality of Internet based banking using combined fuzzy AHP and fuzzy TOPSIS. Tehnicki vjesnik, 23 (4), 1109-1116. DOI: 10.17559/TV-20140801181553

[32] Patil S.K. \& Kant, R. (2014). A fuzzy AHP-TOPSIS framework for ranking the solutions for Knowledge Management adoption in Supply Chain to overcome its barriers. Expert Systems with Applications, 41(2), 679-693. DOI:10.1016/j.eswa.2013.07.093

[33] Peng, A. T., Pike, S. \& Roos, G. (2007). "Intellectual capital and performance indicators: Taiwanese healthcare sector". Journal of Intellectual Capital, 8(3), 538-556, DOI: 10.1108/14691930710774902

[34] Prakash, C. \& Barua, M.K. (2015). Integration of AHP-TOPSIS method for prioritizing the solutions of reverse logistics adoption to overcome its barriers under fuzzy environment. Journal of Manufacturing Systems, 37(3), 599-615. DOI: 10.1016/j.jmsy.2015.03.001

[35] Pramanik, D., Haldar, A., Mondal, S.C., Naskar, S.K. \& Ray, A. (2017). Resilient supplier selection using AHP-TOPSIS-QFD under a fuzzy environment. International Journal of Management Science and Engineering Management, 12(1), 45-54. DOI: 10.1080/17509653.2015.1101719

[36] Roos, G., Pike, S. and Fernstorm, L. (2005). Managing intellectual capital in practice, Elsevier, Oxford.

[37] Samvedi, A., Jain, V. \& Cahn, F.T.S. (2013). Quantifying risks in a supply chain through integration of fuzzy AHP and fuzzy TOPSIS. International Journal of Production Research, 51 (8), 2433-2442. DOI: 10.1080/00207543.2012.741330

[38] Şengül, U., Eren, M., Shuraz, S. E., Gerder, V. \& Şengül, A. (2015). Fuzzy TOPSIS method for ranking renewable energy supply systems in Turkey. Renewable Energy, 75 (1), 617-625. DOI: 10.1016/j.renene.2014.10.045

[39] Shih, H. S., Shyur, H. J. \& Lee, E. S. (2007). An extension of TOPSIS for group decision making. Mathematical and Computer Modelling, 45(7), 801-813. DOI: 10.1016/j.mcm.2006.03.023

[40] Skare, M., \& Tomic, D. (2014). Examining the link between innovation, productivity and growth: A global view. Amfiteatru Economic, 16(36), 606

[41] Stewart, T. A. (1991), Brainpower: intellectual capital is becoming corporate America's most valuable asset and can be its sharpest competitive weapon; the challenge is to find what you have - and use it". Fortune, 123(1), 44-60

[42] Syverson, C. (2011). What determines productivity?. Journal of Economic literature, 49(2), 326-365. DOI: $10.1257 /$ jel.49.2.326

[43] Tadic, D., Aleksic, A., Stefanovic, M. \& Arsovski, S. (2014). Evaluation and Ranking of Organizational Resilience Factors by Using a Two-Step Fuzzy AHP and Fuzzy TOPSIS. Mathematical Problems in Engineering, 2014, 13 DOI: 10.1155/2014/418085

[44] Tadic, D., Gumus, A.T., Arsovski, S., Aleksic, A. \& Stefanovic, M. (2013). An evaluation of quality goals by using fuzzy AHP and fuzzy TOPSIS methodology. Journal od Intelligent \& Fuzzy Systems, 25(3), 547-556. DOI: 10.3233/IFS-120659

[45] Van Laarhoven, P. J. M. \& Pedrcyz, W. (1983). A fuzzy extension of Saaty's priority theory. Fuzzy Sets and Systems, 11(1-3), 229-241. DOI: 10.1016/S0165-0114(83)80082-7

[46] Vinodh, S., Prasanna, M. \& Prakash, N.H. (2014). Integrated Fuzzy AHP-TOPSIS for selecting the best plastic recycling method: A case study. Applied Mathematical Modelling, 39(19-20), 4662-4672. DOI: 10.1016/j.apm.2014.03.007

[47] Zadeh, L.A. (1965). Fuzzy Sets. Information and Control, 8(3), 338-353. DOI: 10.1016/S00199958(65)90241-X

[48] Zare, K, Mehri-Tekmeh, J. \& Karimi S. (2015). A SWOT framework for analyzing the electricity supply chain using an integrated AHP methodology combined with fuzzy-TOPSIS. International Strategic Management Review, 3(1-2), 66-80. DOI: 10.1016/j.ism.2015.07.001

[49] Zyoud, S.H., Kaufmann, L., Shaheen, H., Samhan, S. \& Fuchs-Hanusch, D. (2016). A framework for water loss management in developing countries under fuzzy environment: Integration of Fuzzy AHP with Fuzzy TOPSIS. Expert Systems with Applications, 61(2016), 86-105. DOI: 10.1016/j.eswa.2016.05.016 


\section{APPENDIX}

\section{FAHP-TOPSIS Framework} Fuzzy Analytic Hierarchy Process (FAHP)

In order to deal with uncertain and imprecise data, numerous FAHP methodologies are proposed in the literature by various authors (Van Laarhoven \& Pedrycz, 1983; Buckley, 1985; Chang, 1996). The FAHP method was developed for hierarchical problems solving. It represents a systematic approach to selecting alternatives and solving problems using the concept of fuzzy sets theory (Zadeh, 1965) and the AHP method, implemented through the use of triangular fuzzy numbers (Chang, 1996). A fuzzy set is a class of objects characterised by membership functions, where each object has a membership function in the interval $[0,1]$.

A fuzzy set is usually mark as " $"$ ", and defined by subset $\tilde{M}$ with the membership function $\mu(x \mid \tilde{M})$. Triangular fuzzy numbers are special classes of fuzzy numbers whose membership is defined by three real numbers, expressed as $(l, m, u)$ (Dubois \& Prade, 1978). The symbols $(l, m, u)$ represent the minimum possible value, the possible value and the maximum possible value, respectively. Triangular fuzzy numbers are used for the preferences of one criterion over another. Therefore, the Triangular fuzzy scale of preferences or Linguistic scale of importance is given in Table 1.

The most commonly used is the FAHP methodology which was extensively analysed by Chang (1996): let $X=\left\{x_{1}, x_{2}, \ldots, x_{n}\right\}$ be a set of objects, and let $G=\left\{g_{1}, g_{2}, \ldots, g_{n}\right\}$ be a set of goals. According to the methodology of extended analysis which was set up by Chang (1996), an extended analysis of goal $g_{i}$ is performed for every taken object. The values of extended analysis $m$ for each object can be represented as follows:

$$
M_{g i}^{1}, M_{g i}^{2}, \ldots, M_{g i}^{n}, \quad \mathrm{i}=1,2, \ldots, \mathrm{n}
$$

where $M_{g i}^{j}, \quad(j=1,2, \ldots, m)$ are fuzzy triangular numbers. Chang's extended analysis consists of the following steps:

Step 1: The values of fuzzy extensions for the $i$-th object are given in Expression (2):

$$
\begin{gathered}
S_{i}=\sum_{j=1}^{m} M_{g i}^{j} \otimes\left[\sum_{i=1}^{n} \sum_{j=1}^{m} M_{g i}^{j}\right]^{-1} \\
{\left[\sum_{i=1}^{n} \sum_{j=1}^{m} M_{g i}^{j}\right]^{-1}, \text { it is necessary to p }}
\end{gathered}
$$

In order to obtain the expression $\left[\sum_{i=1}^{n} \sum_{j=1}^{m} M_{g i}^{j}\right]^{-1}$, it is necessary to perform additional fuzzy operations with $m$ values of the extended analysis, which is represented by Expressions (3), (4):

$$
\begin{gathered}
\sum_{j=1}^{m} M_{g i}^{j}=\left(\sum_{j=1}^{m} l_{i} \sum_{j=1}^{m} m_{i} \sum_{j=1}^{m} u_{i}\right), \\
\sum_{i=1}^{n} \sum_{j=1}^{m} M_{g i}^{j}=\left(\sum_{j=1}^{n} l_{i} \sum_{j=1}^{n} m_{i} \sum_{j=1}^{n} u_{i}\right),
\end{gathered}
$$

In other words, it is necessary to calculate the inverse vector using Expression (5): 


$$
\left[\sum_{i=1}^{n} \sum_{j=1}^{m} M_{g i}^{j}\right]^{-1}=\left(\frac{1}{\sum_{i=1}^{n} u_{i}}, \frac{1}{\sum_{i=1}^{n} m_{i}}, \frac{1}{\sum_{i=1}^{n} l_{i}}\right)
$$

Step 2: The degree of possibility for $M_{2}=\left(1_{2}, \mathrm{~m}_{2}, \mathrm{u}_{2}\right)$ and $M_{1}=\left(\mathrm{l}_{1}, \mathrm{~m}_{1}, \mathrm{u}_{1}\right)$ is defined by Expression (6):

$$
V\left(M_{2} \geq M_{1}\right)=\mathrm{y} \geq \mathrm{x}\left\lfloor\min \left(\mu_{M_{1}}(x), \mu_{M_{2}}(\mathrm{y})\right)\right\rfloor,
$$

It can be represented in the following manner by Expression (7):

$$
\begin{aligned}
V\left(M_{2} \geq M_{1}\right)=\operatorname{hgt}\left(\mathrm{M}_{1} \cap M_{2}\right)=\mu_{M_{2}}(d) \\
=\left\{\begin{array}{l}
1, \text { if } m_{2} \geq m_{1} \\
0, \text { if } l_{1} \geq u_{2} \\
\frac{l_{1}-u_{2}}{\left(m_{2}-u_{2}\right)-\left(m_{1}-l_{1}\right)}, \text { otherwise }
\end{array}\right.
\end{aligned}
$$

where $d$ is the ordinate of the highest intersection point $D$ between $\mu_{M_{1} \text { and }} \mu_{M_{2}}$ (Figure 1). In order to compare $M_{1}$ and $M_{2}$, values of both $V\left(M_{1} \geq M_{2}\right)$ and $V\left(M_{2} \geq M_{1}\right)$ are needed.

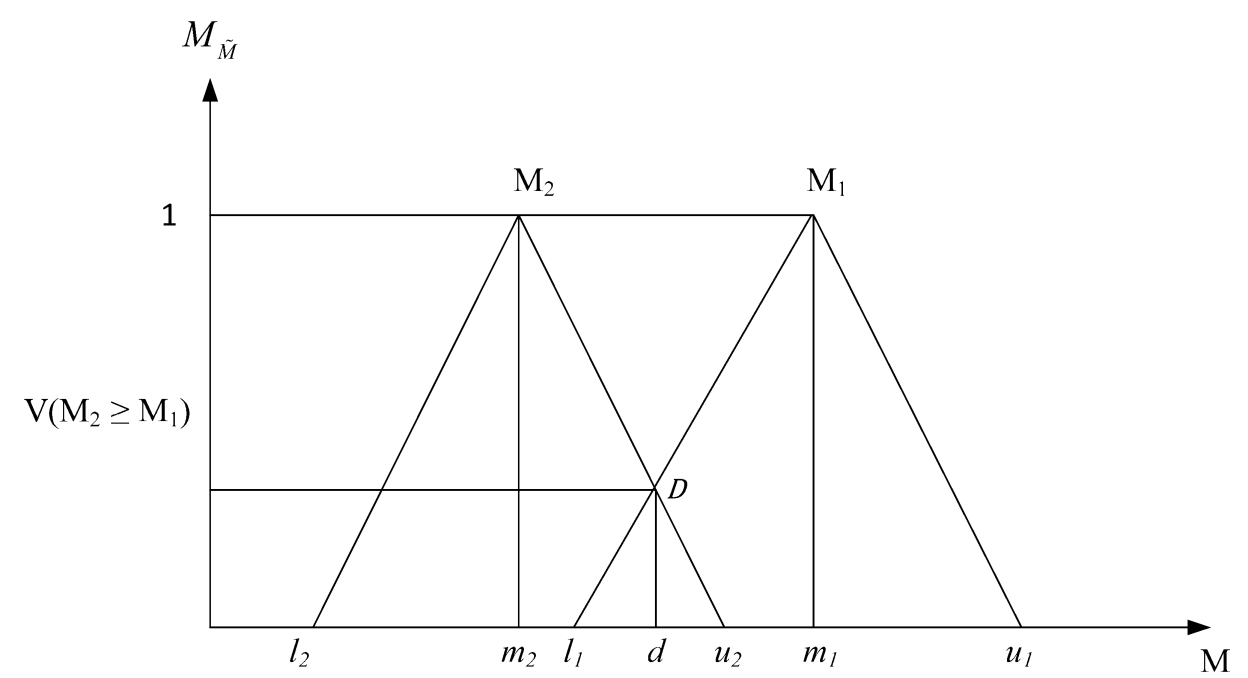

Figure 1: The intersection between $M_{1}$ and $M_{2}$

Step 3: The degree of possibility for a convex fuzzy number to be greater than the $k$ convex numbers $M_{i}, \quad(i=1,2, \ldots, k)$ can be defined by Expression (8): 


$$
\begin{aligned}
& V\left(\mathrm{M} \geq M_{1}, M_{2}, \ldots, M_{k}\right)=\mathrm{V}\left[\left(M \geq M_{1}\right) \text { and }\left(M \geq M_{2}\right) \text { and } \ldots \text { and }\left(M \geq M_{k}\right)\right]= \\
& =\min V\left(M \geq M_{i}\right), \quad i=1,2,3, \ldots, k
\end{aligned}
$$

Let us assume that Expression (9) is true:

$$
d^{\prime}\left(\mathrm{A}_{i}\right)=\min V\left(\mathrm{~S}_{i} \geq S_{k}\right)
$$

for $k=1,2, \ldots, n ; k \neq i$. The weight vector is obtained by Expression (10):

$$
W^{\prime}=\left(d^{\prime}\left(\mathrm{A}_{1}\right), d^{\prime}\left(\mathrm{A}_{2}\right), \ldots, d^{\prime}\left(\mathrm{A}_{n}\right)\right)^{T}
$$

where $A_{i}, \quad i=(1,2, \ldots, n)$ consists of $n$ elements.

Step 4: Through normalization, the weight vectors are reduced to Expression (11):

$$
W=\left(d\left(\mathrm{~A}_{1}\right), d\left(\mathrm{~A}_{2}\right), \ldots, d\left(\mathrm{~A}_{n}\right)\right)^{T}
$$

where $W$ does not represent a fuzzy number (Büyüközkan et al., 2008; Kahraman et al., 2006).

\section{TOPSIS method (Technique for Order Performance by Similarity to Ideal Solution)}

The TOPSIS is one of the most used classical multi-criteria decision-making methods. This method is very useful for real problem solving, providing the optimal solution or the alternatives' ranking. The TOPSIS ranks alternatives according to their distance from the Positive ideal solution (PIS) and Negative ideal solution (NIS). PIS maximises the benefit criteria and minimises the cost criteria, while NIS maximises the cost criteria and minimises the benefit criteria (). The fundamental principle is that the chosen alternative should have the shortest distance from the PIS and the farthest distance from the NIS (Abo-Sinna \& Amer, 2005; Jahanshahloo et al., 2006; Shih, Shyur \& Lee, 2007; Gumus, 2009).

The TOPSIS methodology presented by (Hwang \& Yoon, 1981) consists of the following steps:

Step 1: The decision matrix is normalised through the application of Expression (12):

$$
r_{i j}=\frac{W_{i j}}{\sqrt{\sum_{j=1}^{J} W_{i j}^{2}}}, j=1,2, \ldots, J ; i=1,2, \ldots, n
$$

Step 2: A weighted normalised decision matrix is obtained by multiplying the normalised matrix with the weights of the criteria, Expression (13):

$$
V_{i j}=W_{i} * r_{i j}, \quad j=1,2, \ldots, n ; \quad i=1,2, \ldots, n
$$

Step 3: PIS (maximum value) and NIS (minimum value) are determined by Expressions $(14,15)$ :

$$
\begin{gathered}
A^{*}=\left\{V_{1}^{*}, V_{2}^{*}, \ldots, V_{n}^{*}\right\} \\
A^{-}=\left\{V_{1}^{-}, V_{2}^{-}, \ldots, V_{n}^{-}\right\}
\end{gathered}
$$

Step 4: The distance of each alternative from PIS and NIS is calculated using Expressions (16), (17):

$$
d_{i}^{*}=\sqrt{\sum_{j=1}^{n}\left(V_{i j}-V_{j}^{*}\right)^{2}}, j=1,2, \ldots, J
$$




$$
d_{i}^{-}=\sqrt{\sum_{j=1}^{n}\left(V_{i j}-V_{j}^{-}\right)^{2}}, j=1,2, \ldots, J
$$

Step 5: The closeness coefficient for each alternative $\left(C C_{i}\right)$ is calculated by applying Expression (18):

$$
C C_{i}=\frac{d_{i}^{-}}{d_{i}^{*}+d_{i}^{-}}
$$

Step 6: At the end of the analysis, the ranking of alternatives is made possible by comparing the $\left(C C_{i}\right)$ values.

\section{|||||||||||||||||||||||||||||||| $\mid$ abouthenturar}

\section{Snežana Knežević \\ University of Belgrade, Faculty of Organizational Sciences, Serbia knezevic.snezana@fon.bg.ac.rs}

Snežana Knežević was born in Pančevo (Jabuka), where she finished school of economics. She graduated from the Faculty of Economics at the University of Belgrade, where she also got her MSc degree. She got her PhD degree at the Faculty of Organizational Sciences at the University of Belgrade. Her fileds of interest include accounting, financial analysis, and valuation. She is bilingual fluency in both English and French. She has published several monographs and she has produced over 50

papers of scientific and professional orientation in the country and abroad. She is currently working at the Faculty of Organizational Sciences in Belgrade, Department of Financial Management and Accounting as an Associate professor. She is the owner of the Agency for accounting and consulting services.

\section{Ksenija Mandić \\ University of Belgrade, Faculty of Organizational Sciences, Serbia}

Ksenija Mandić received her BSc, MSc and the PhD degrees in Faculty of Organizational Science from the University of Belgrade, Serbia, in 2006, 2008 and 2015 respectively. She works in telecommunication company Crony since 2007. Her research interests are decision making theory, supply chain management, multi-criteria decision

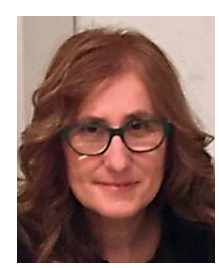
making methods, fuzzy logic and Interpolative Boolean Algebra.

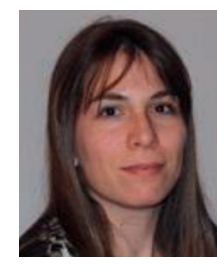




\section{Aleksandra Mitrović \\ University of Kragujevac, Faculty of Hotel Management and Tourism aleksandra.stankovic@kg.ac.rs}

Aleksandra Mitrović, Ph.D., works as a Assistant Professor at the Faculty of Hotel Management and Tourism in Vrnjačka Banja, University of Kragujevac. She completed her Bachelor Studies in Accounting and Corporate Finance as well as her Master studies at the Faculty of Economics in Kragujevac. She got her PhD degree in 2016. The fields of her scientific and professional interests are related to Accounting and Finance.

\section{Veljko Dmitrović University of Belgrade, Faculty of Organizational Sciences, Serbia dmitrovicv@fon.bg.ac.rs}

Veljko Dmitrović works at the Faculty of Organizational Sciences, University of Belgrade, at the Department of Financial Management and Accounting as assistant professor. He achieved PhD degree at the Faculty of Organizational Sciences. He achieved his MSc degree in Financial Management at the Faculty of Organizational Sciences, University of

Belgrade, and his BSc and MA degrees in Marketing Management at the Faculty of Economics in Subotica, University of Novi Sad. So far he has authored and coauthored more than 50 papers published in international and national journals and conferences.

$\mathrm{He}$ has been involved in several research projects. Before the academic career he gained practical experience working for five years in "Fidelinka" a.d., Subotica.

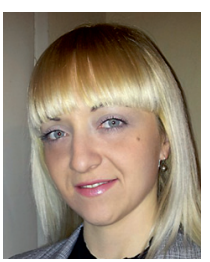

Boris Delibašić

University of Belgrade, Faculty of Organizational Sciences, Serbia boris.delibasic@fon.bg.ac.rs

Boris Delibašić is professor at the University of Belgrade - Faculty of Organizational

Sciences, Serbia. His research interests lie in business intelligence, data mining, machine learning, multicriteria decision analysis, and decision support systems. He serves in editorial boards of several international journals. He is a coordinator of the EURO working group on Decision Support Systems. He obtained his PhD in 2007 from the University of Belgrade. He was awarded with the Fulbright Visiting Scholar Grant in 2011. He speaks fluently English, and German, and speaks also Russian, French, and Italian. His research profile is available at https://www.researchgate.net/profile/Boris_Delibasic
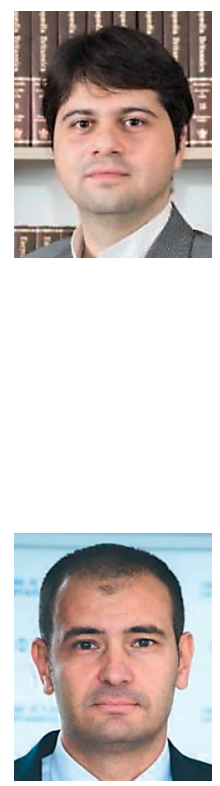